\title{
Digestibility of dietary nutrients and morphohistological changes in the pancreas and duodenum of broiler chickens against the background of replacement of feed antibiotics with a complex phytobiotic drug
}

\author{
E. V. Shatskikh ${ }^{\bowtie}$, A. I. Nufer ${ }^{1}$, L. I. Drozdova ${ }^{1}$ \\ ${ }^{1}$ Ural State Agrarian University, Ekaterinburg, Russia \\ E-mail: evshackih@yandex.ru
}

\begin{abstract}
The study is aimed at studying the indices of the digestibility of nutrients in broiler chickens' diet and morphohistological changes in the duodenum and pancreas with additional administration and when replacing the feed antibiotic in the feed for a complex preparation, including phytoextracts, essential oils and protected organic acids. The study is based on the methods of industrial testing of the effectiveness of feed and commercial products in accordance with the methods of the Federal Research Center "VNITIP" RAS (2013). For calculations, the method of variation statistics is used with the use of the PC "Microsoft Excel". The assessment of the statistical significance of differences between groups was carried out using the Student's t-test. Results. It was found that the tested feed additive, which includes essential oils, protected organic acids, and hot pepper extract, promoted an increase in the digestion of fiber and fat by broiler chickens. The morphohistological study has shown that the processes of food digestion during the active work of the pancreas create conditions for the normal life of the bird without the manifestation of pathological processes. Scientific novelty of the work. Recently, the use of antibiotic drugs has been widely discussed in scientific circles and in the general press, shaping public opinion. There has been a significant increase in the number of publications dealing with the use of alternative antibiotics additives that promote the growth of poultry, enhance the immune response. Under these conditions, for the first time in a comparative study, the reserves of increasing the productive qualities of poultry were substantiated due to the use in the composition of compound feed in addition and instead of feed antibiotics additives, including phytoextracts, essential oils and protected organic acids. Namely, new data were obtained on the influence of the studied feed factor on the digestibility and use of nutrients of feed, the morphohistological state of the duodenum and pancreas.
\end{abstract}

Keywords: broiler chickens, nutrient digestibility, pancreas, duodenum, morphohistological changes, phytobiotics, feed antibiotics, essential oils, protected organic acids.

For citation: Shatskikh E. V., Nufer A. I., Drozdova L. I. Digestibility of dietary nutrients and morphohistological changes in the pancreas and duodenum of broiler chickens against the background of replacement of feed antibiotics with a complex phytobiotic drug // Agrarian Bulletin of the Urals. 2020. No. 12 (203). Pp. 61-67. DOI: ...

Paper submitted: 19.09.2020.

\section{Introduction}

Strict regulation of feed antibiotics use does not fully ensure the safety of poultry products. At the beginning of 2018 , the quality of Russian meat products was discussed, in particular, issues of exceeding the permissible content of antibiotics in it. In March of the same year, the Rosselkhoznadzor introduced an enhanced laboratory control regime over the products of a number of enterprises producing livestock products. Tightening quality control of domestic products, requirements from government agencies and large customers (fast food restaurants, federal retail chains) are forcing manufacturers to reconsider approaches to many production processes. In particular, increased control over the residual content of antibiotics in finished products is becoming urgent. Moreover, more and more often Russian poultry producers are thinking about switching to growing technologies without the use of antibiotics. Considering the experience of Western companies and market trends, it can be argued that the future belongs to antibiotic-free products. And sooner or later, all manufacturers will have to deal with this issue [1].

In the 70-80s of the last century, there were shown specific mechanisms of the formation of microorganisms' antibiotics' resistance. Today this is a big problem and requires an urgent solution. The debate about whether antibiotic agents can be used in animal husbandry have been going on for an infinitely long time. Neither the acuteness of such discussions, nor the conviction of each of the parties that they are right, change. However, the balance of forces is gradually shifting: if ten to fifteen years ago, relatively few opposed antibiotic growth stimulants, now there are so many opponents that they can no longer be ignored. 
Antibiotics used for therapeutic purposes and to stimulate the growth of young animals accumulate in significant quantities in food products - meat, milk, eggs. The free concentration of antibiotics for a short period of time is excreted from the animal's body with waste products - feces, urine, products (milk, eggs), and associated with proteins and other components remains in the body for a long time. The antibiotic drugs excreted from the body enter the soil as part of organic fertilizers and then accumulate in plants [2].

The beginning of the use of feed antibiotics in poultry farming radically changed veterinary medicine. Antibiotics have made it possible to successfully fight many infections and intestinal disorders that are inevitable in the industrial poultry industry. They significantly improved growth rates, feed conversion and increased safety of the poultry population. For many years of use, feed antibiotics have proven their unconditional zootechnical effectiveness [3, p. 160].

Antimicrobial drugs act according to general pharmacological laws, despite their high specificity, they are quite effective only if the developed instructions are strictly followed. If the conditions are not met, antibiotic agents show little effect, and in some cases they can cause harm.

A World Health Organization report published in April 2014 states that "this serious threat is no longer just a prediction for the future, as it is already manifesting itself right now in every region of the world and can negatively affect everyone, regardless of age, in every country. Antibiotic resistance is a phenomenon when bacteria change so much that antibiotics no longer have any effect on the human body, who need them to fight infection, and this is now one of the most serious threats to human health" [4], [5].

The World Health Organization has concluded that inappropriate use of antibiotics in animal husbandry is a major contributor to the emergence and spread of antibiotic-resistant microorganisms, and that there is a need to limit the use of antibiotics as growth promoters in animal feed. The International Epizootic Office has added a set of guidelines to the World Veterinary Code with recommendations for establishing national surveillance and monitoring programs for antimicrobial resistance, controlling the amount of antibiotics used in animal husbandry, and proposals for ensuring the appropriate and appropriate use of antibiotic drugs. Another recommendation is the implementation of methodologies to help identify associated risk factors and assess the risk of antibiotic resistance [6, pp. 277-279].
In this regard, the biological rationale for the use of drugs that are an alternative to feed antibiotics is now the most logical step, especially since foreign manufacturers have already crossed this line and can share their experience [7, pp. 26-28], [8, pp. 66-68]. At the time of the prohibition of antibiotics, European farms experienced a deep crisis. However, at present, a truly invaluable experience has been accumulated in the successful use of drugs that are an alternative to growth-stimulating antibiotics [9, pp. 25-28], [10, p. 22], [11, pp. 48-50], [12, pp. 53-56], [13, pp. 39-40].

Complex preparations, which include components with pronounced growth-stimulating properties: phytobiotics, protected organic acids, essential oils, can be considered relevant and effective [14, p. 43, 47], [15, pp. 798-809], [16, pp. 2645].

\section{Methods}

The aim of the study was to study the indices of the digestibility of nutrients in the diet and morphohistological changes in the duodenum and pancreas with the additional introduction and replacement of the feed antibiotic in the feed for a complex preparation, including phytoextracts, essential oils and protected organic (fumaric acid, sorbic acid, DL-malic acid, citric acid).

The experimental part of the work was carried out in the production conditions of JSC Poultry Farm "Sredneuralskaya" on broiler chickens of the "Ross 308" cross in 2019.

According to the scheme of scientific and economic experience (table 1) at the day-old age, 3 groups of broiler chickens with an average live weight of $43 \mathrm{~g}$ were formed. The bird was divided by sex. Males ( 80 heads) and chickens ( 80 heads) were kept in different cages during the research. The experiment continued throughout the entire growing period.

The control group received the basic diet (BD) adopted on the farm, with the nutritional value corresponding to the recommendations for the cross. From the $1^{\text {st }}$ to the $21^{\text {st }}$ days of growing broiler chickens, the feed antibiotic Albacin was included in the composition of the BD in the amount of $300 \mathrm{~g} / \mathrm{t}$ of compound feed, and from the $22^{\text {nd }}$ to $30^{\text {th }}$ days of growing the feed antibiotic Nosigeptide $-250 \mathrm{~g} / \mathrm{t}$ of compound feed. Chickens of the $1^{\text {st }}$ experimental group, in addition to the $\mathrm{BD}$ from the $1^{\text {st }}$ day of growing until the end of the feeding period, included a complex phytobiotic preparation in the amount of $1 \mathrm{~kg} / \mathrm{t}$ of compound feed. In the diet of broilers of the $2^{\text {nd }} \mathrm{ex}-$ perimental group, the feed antibiotic was replaced with a test additive in the amount of $1 \mathrm{~kg} / \mathrm{t}$ of compound feed.

Table 1

Scheme of scientific and economic experience

\begin{tabular}{|c|c|c|}
\hline Group & $\begin{array}{l}\text { The number } \\
\text { of animals }\end{array}$ & Feeding conditions \\
\hline \multirow{2}{*}{ Control } & o 80 & \multirow{2}{*}{$\begin{array}{l}\text { The main diet included a feed antibiotic: } \\
\text { from day } 1 \text { to day } 21 \text {-Albacin in the amount of } 300 \mathrm{~g} / \mathrm{t} \text { of compound feed and } \\
\text { from day } 22 \text { to day } 30 \text {-Nosiheptide- } 250 \mathrm{~g} / \mathrm{t} \text { of compound feed }\end{array}$} \\
\hline & ㅇ 80 & \\
\hline \multirow{2}{*}{$1^{s t}$ experienced } & ठ 80 & \multirow{2}{*}{$\begin{array}{l}\text { The main diet }+ \text { the studied additive in the amount of } 1 \mathrm{~kg} / \mathrm{t} \text { of compound feed } \\
\text { Period of use: from day } 1 \text { to the end of fattening }\end{array}$} \\
\hline & ㅇ 80 & \\
\hline \multirow{2}{*}{$2^{\text {nd }}$ experienced } & $\widehat{\partial} 80$ & \multirow{2}{*}{$\begin{array}{l}\text { Experimental diet: the feed antibiotic in the OR was replaced with the studied } \\
\text { additive in the amount of } 1 \mathrm{~kg} / \mathrm{t} \text { of compound feed. } \\
\text { Period of use: from day } 1 \text { to the end of fattening }\end{array}$} \\
\hline & 우 80 & \\
\hline
\end{tabular}


Coefficients of digestibility of nutrients by broiler chickens, \% $(n=5)$

\begin{tabular}{|l|c|c|c|}
\hline \multirow{2}{*}{\multicolumn{1}{c|}{ Indicator }} & \multicolumn{3}{c|}{ Group } \\
\cline { 2 - 4 } & Control & $\mathbf{1}^{\text {st }}$ experienced & $\mathbf{2}^{\text {nd }}$ experienced \\
\hline Dry matter & 67.9 & 66.1 & 67.3 \\
\hline Crude protein & 92.3 & 92.0 & 91.6 \\
\hline Crude fat & 75.4 & 75.7 & 80.3 \\
\hline Crude fiber & 10.6 & 13.8 & 21.6 \\
\hline Nitrogen-free extractives & 81.9 & 78.9 & 76.8 \\
\hline
\end{tabular}

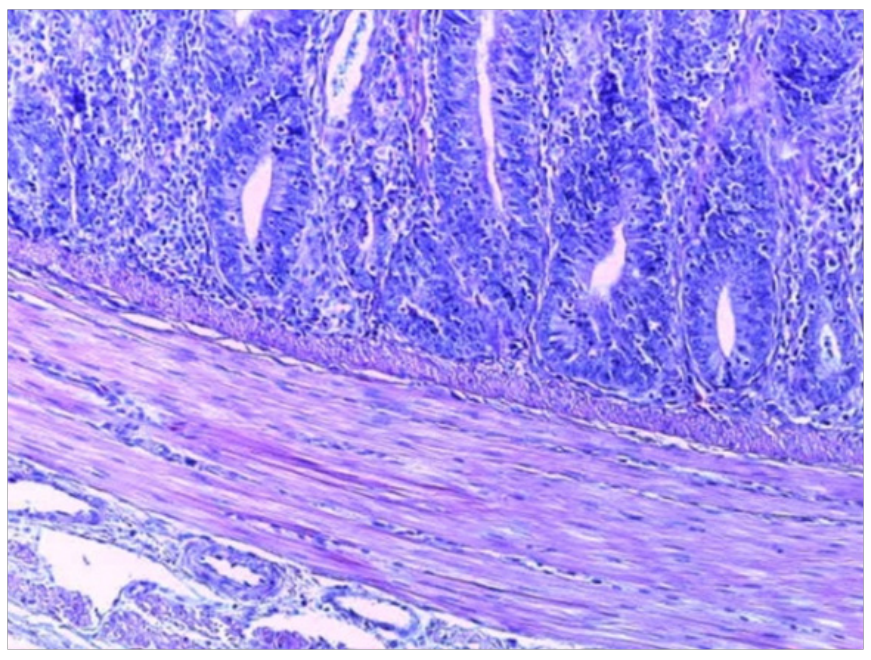

Fig. 1. Duodenum of a control group of birds 22-day-old

To determine the digestibility of nutrients, a balance (physiological) experiment was carried out. For this, at the age of 28 days, 5 average ones were selected for their group, according to the live weight of broiler cockerels. The experiment was carried out in accordance with the recommended methods of the Federal State Budgetary Scientific Institution Federal Scientific Center "All-Russian Scientific Research and Technological Institute of Poultry" of the Russian Academy of Sciences (2013). The selected manure and mixed feed were homogenized and analyzed in the analytical laboratory "Ural Research Institute of Agriculture" - a branch of the Federal State Budgetary Scientific Institution Ural Federal Agrarian Research Center of the Ural Branch of the Russian Academy of Sciences.

The analysis of feed and droppings was carried out according to the generally accepted methods:

1) total nitrogen content - according to the Kjeldahl method (or Dyakov), all-Union State Standard R.51417-99 (\%);

2) content of mass fraction of crude fat - by extraction method, all-Union State Standard 13496.15-97 (\%);

3 ) the content of the mass fraction of crude fiber - by removing acid-alkali-soluble substances from the product and determining the crude fiber, all-Union State Standard 13496.2$97(\%)$.

For morphohistological studies, there were taken samples of the duodenum and pancreas of birds from 3 heads from each group. The material was fixed in a $10 \%$ solution of neutral formalin. The study of general structural changes in organs was carried out on paraffin sections, the preparations were stained with hematoxylin and eosin according to the generally accepted method. All histological examinations were documented by photographing under a microscope.

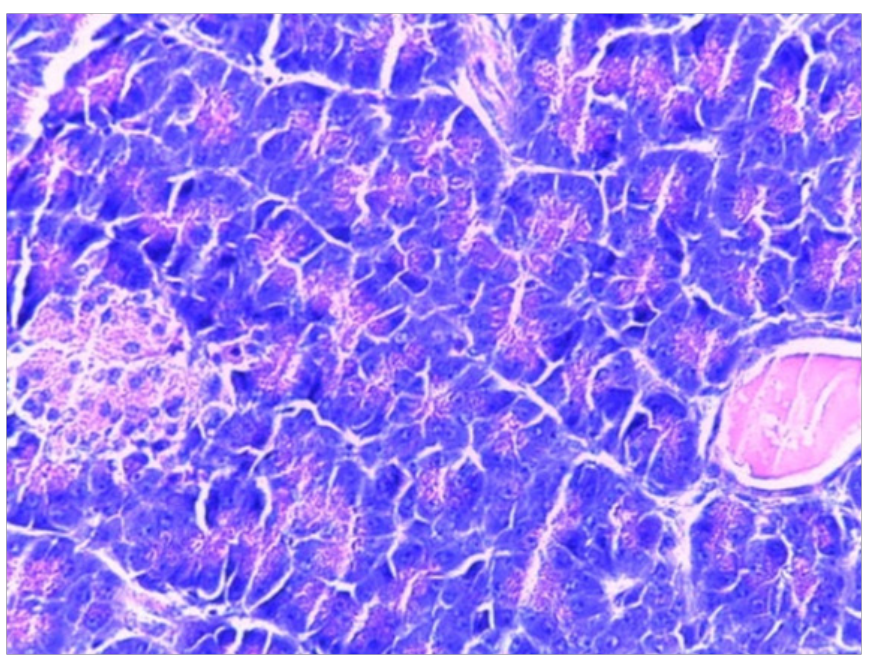

Fig. 2. Pancreas of poultry in the control group 22-day-old

The main experimental data were processed by the method of variation statistics using the PC Microsoft Excel. The statistical significance of the differences between the groups was assessed using the Student's t-test.

\section{Results}

The use of nutrients in the feed of a bird directly affects its performance level. Table 2 shows the nutrient digestibility factors. It was noted that broiler male birds of the $1^{\text {st }}$ and $2^{\text {nd }}$ experimental groups were not significantly inferior to the control in terms of the digestibility of the dry matter of the diet by 1.8 and $0.6 \%$, respectively.

The highest digestibility of feed crude protein was observed in the control group $-92.3 \%$, which is more than in the $1^{\text {st }}$ and $2^{\text {nd }}$ experimental groups by 0.3 and $0.7 \%$, respectively.

The percentage of crude fat digestion in chickens from the control group was $75.4 \%$. In broilers of the $1^{\text {st }}$ and $2^{\text {nd }}$ experimental groups, this indicator was higher by 0.3 and $4.9 \%$, respectively.

The digestion of fiber in the body of chickens is carried out with the help of intestinal microflora enzymes. The highest value for the absorption of fiber was obtained in the $2^{\text {nd }}$ experimental group $-21.6 \%$, which is $11 \%$ more than the control indicator.

In $1^{\text {st }}$ experimental group of broilers, the coefficient of fiber digestibility is $3.2 \%$ higher than the control level. We believe that the increase in fiber digestion in broilers who received a phytobiotic preparation instead of a feed antibiotic is due to the creation of the most favorable conditions in the large intestine of birds for the development of cellulolytic bacteria.

More than half of the dry matter of the feed consists of nitrogen-free extractive substances; this group includes sugar and starch of the feed. The digestibility of nitrogen-free extrac- 
tive substances in the control group was at the level of $81.9 \%$, in chickens $1^{\text {st }}$ and $2^{\text {nd }}$ of the experimental group this indicator was lower than the control values by 3.0 and $5.1 \%$, respectively.

A histological examination of the internal organs of a bird from the control group at the age of 22 days revealed no pathological processes that aggravate the clinical state of the bird. In the duodenum of broilers, all layers were clearly defined, the villi lined with epithelium had a limited outer membrane, and the goblet cells were in a state of moderate secretion (fig. 1).

The pancreas of broiler chickens in the control group at the age of 22 days was in a state of poorly expressed secretion, the islets of Langerhans were not activated, and there was stagnation of secretion in the small ducts of the gland (fig. 2).

In experimental group 1, the examined internal organs of birds at the age of 22 days differed little from those of their peers in the control group during this period of time. In the duodenum, increased secretion was noted (fig. 3), and in the pancreas - stagnation of secretions in the ducts (fig. 4).

In the duodenum of chickens of the $2^{\text {nd }}$ experimental group at 22 days age, the villi were clearly contoured (fig. 5), with the activation of secretion by goblet cells (fig. 6).

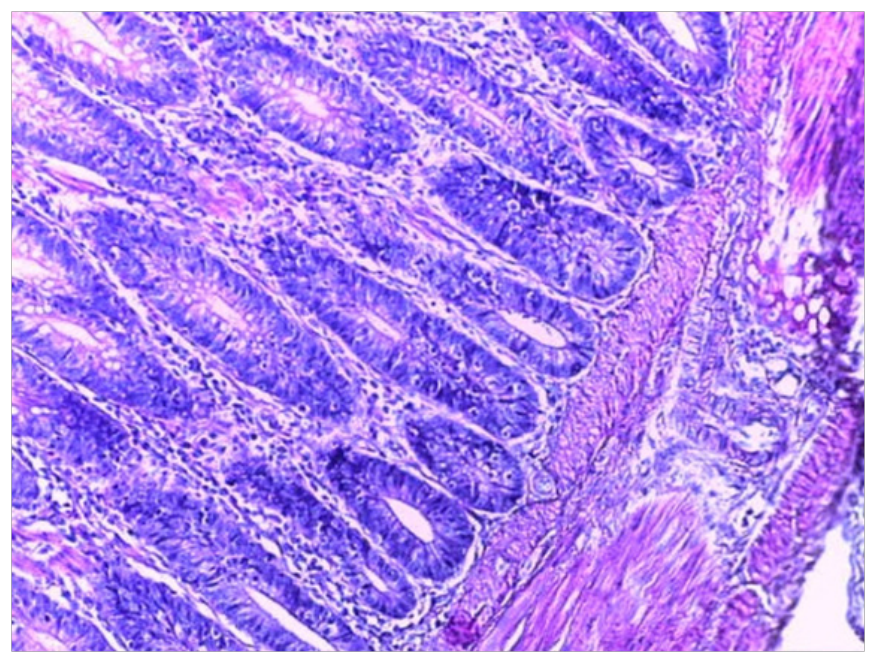

Fig. 3. Duodenum of a 22-day-old bird of the 1st experimental group

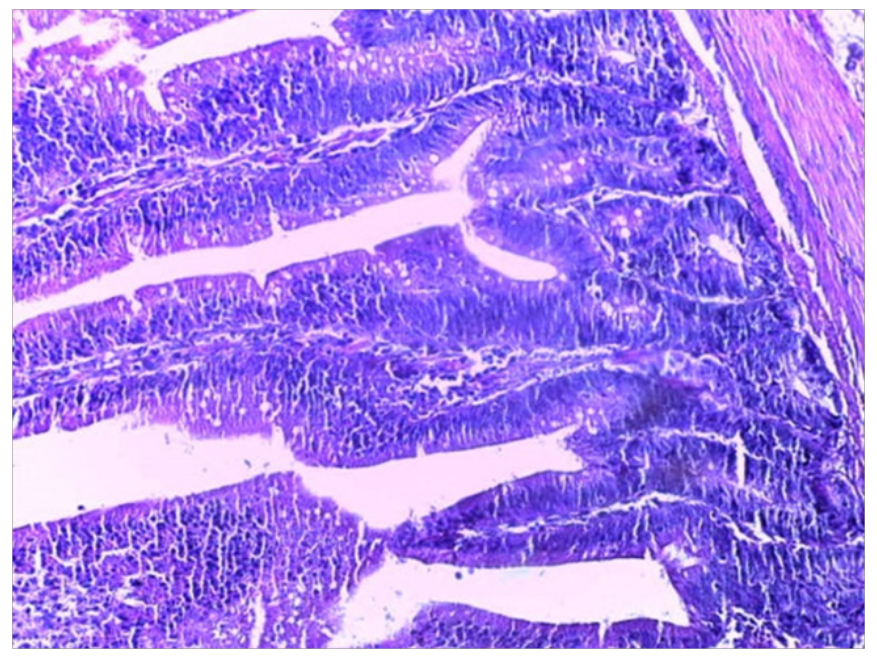

Fig. 5. Duodenum of a 22-day-old bird of the 2 nd experimental group
In the pancreas of 22-day-old broiler chickens of the $2^{\text {nd }}$ experimental group, an increase in the size and activation of secretion in the islets of Langerhans was noted (fig. 7).

At 38 days age in the duodenum in all three males of the control group, were revealed wall thickening, a sharp increase in secretion by goblet cells (fig. 8, 9) and the phenomenon of catarrhal duodenitis (fig. 10).

The duodenum of chickens from the $1^{\text {st }}$ experimental group at the age of 38 days was in a state of slight hypersecretion of the glands (fig. 11), activation of the islets of Langerhans was observed in the pancreas (fig. 12).

In the pancreas of chickens from the control group at 38 days age, a slight activation of the islets of Langerhans was noted (fig. 13), however, most of them had weak secretory activity (fig. 14).

The duodenum of the chickens of the $2^{\text {nd }}$ experimental group at the age of 38 days had a clear outline of the villi without signs of an inflammatory process with moderate secretion (fig. 15).

In all samples of the pancreas of the 2 experimental group, activation of the secretion of the islets of Langerhans was expressed at 38 days (fig. 16).

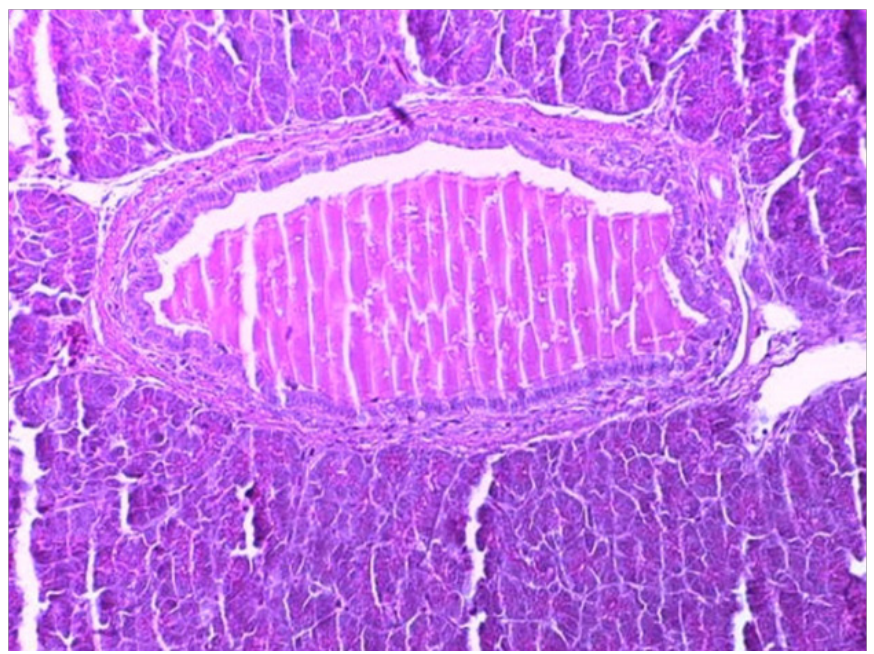

Fig. 4. Pancreas of poultry of the 1st experimental group 22-day-old

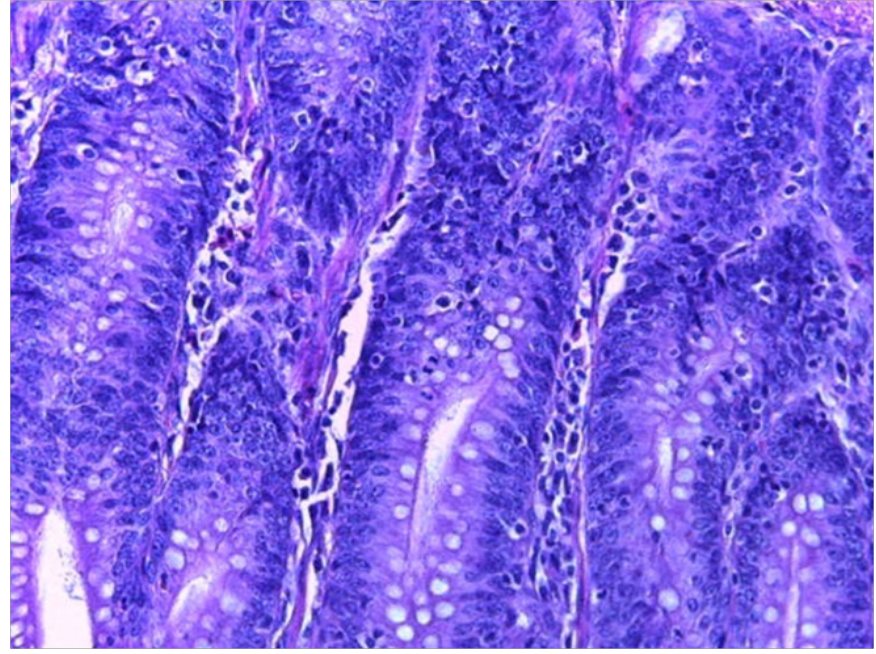

Fig. 6. 12-duodenum of a 22-day-old bird of the 2 nd experimental group 


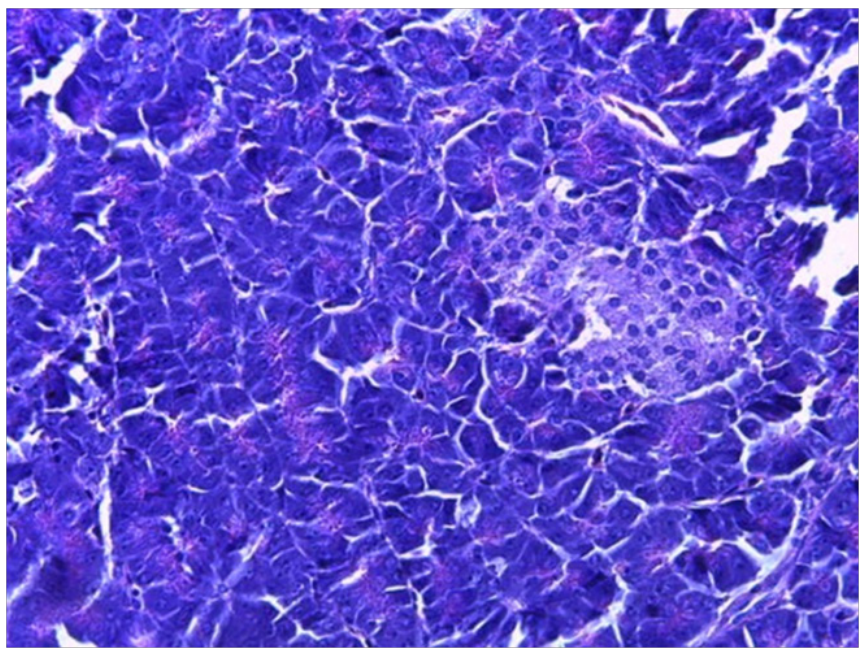

Fig. 7. Pancreas of poultry

of the 2nd experimental group 22-day-old

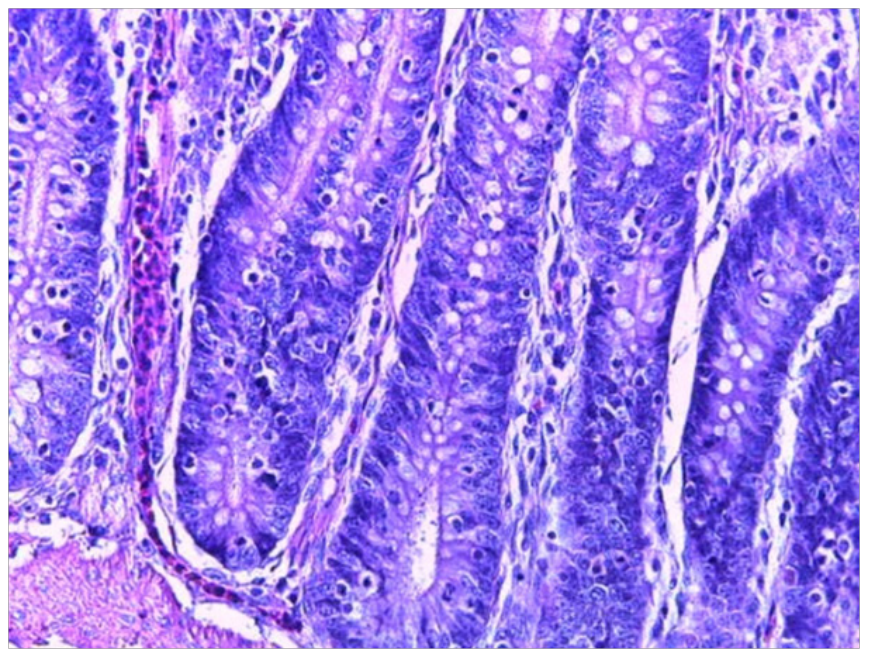

Fig. 9. Duodenum of a control group of birds 38-day-old

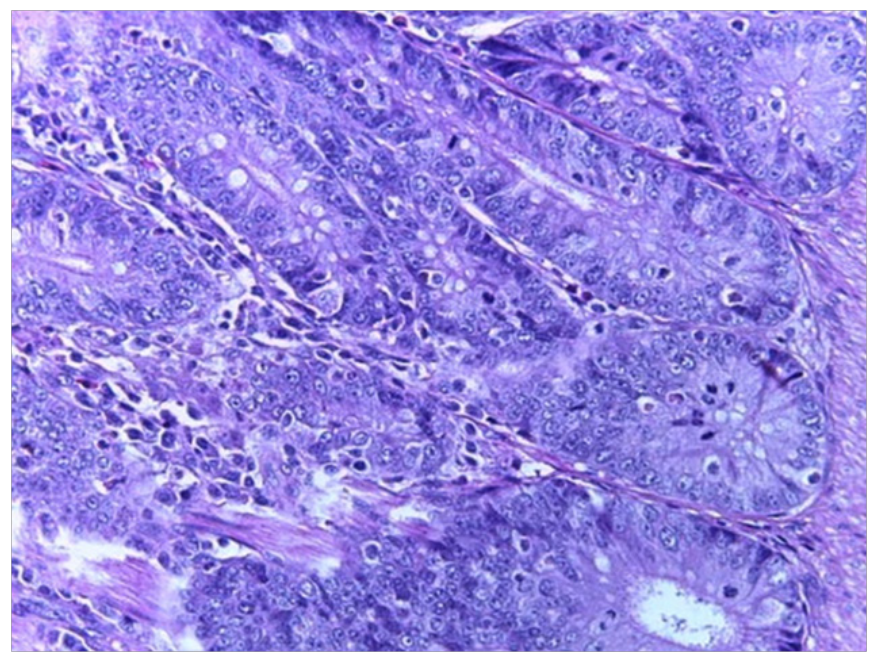

Fig. 11. Duodenum of a 38-day-old bird

of the 1st experimental group

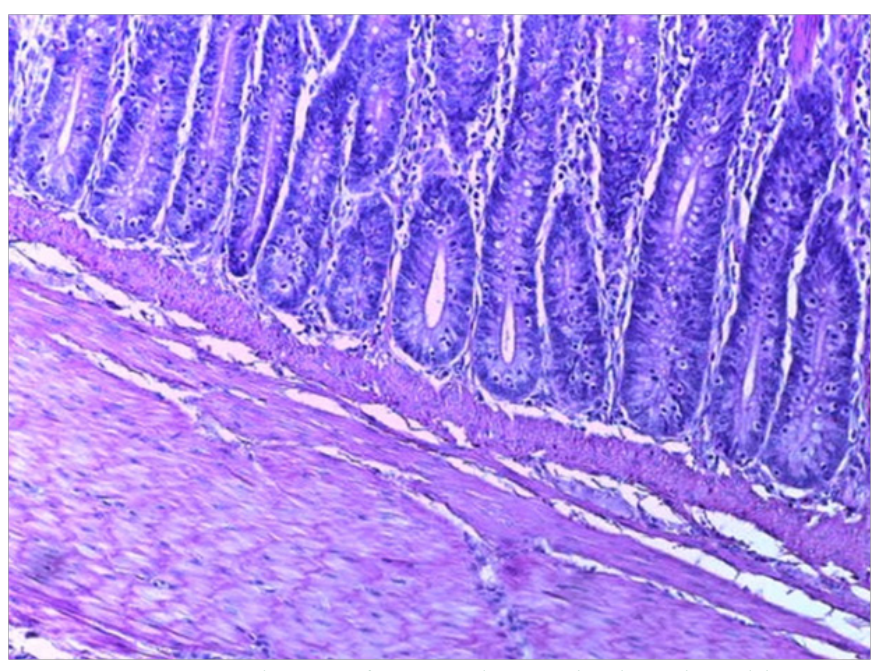

0
0
0
0
00
4
2
5
0
$\sigma$
0
0
0
0
0
5
0
0
0
0.
0
$\infty$

Fig. 8. Duodenum of a control group bird 38-day-old

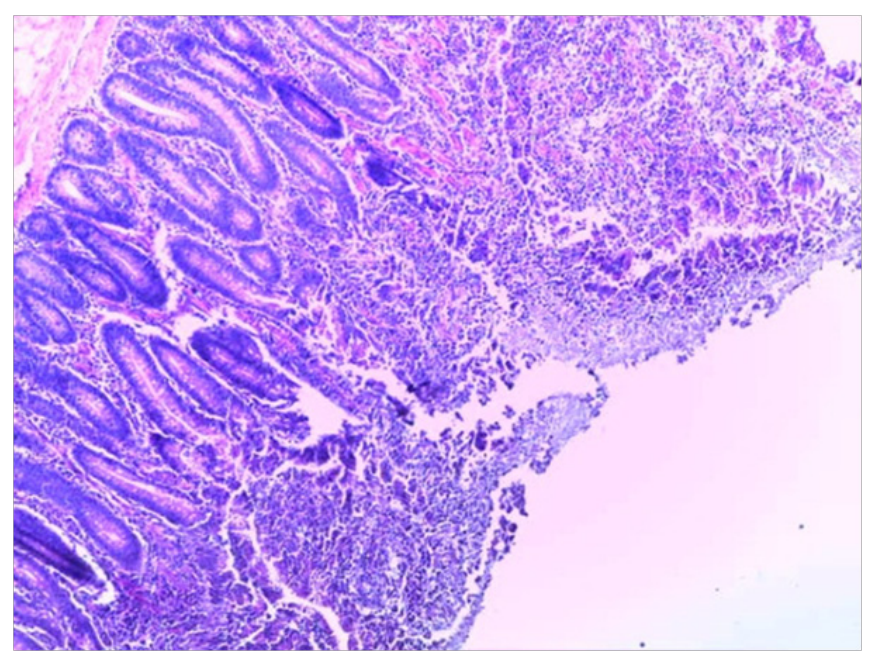

Fig. 10. Duodenum of a 38-day-old control group bird

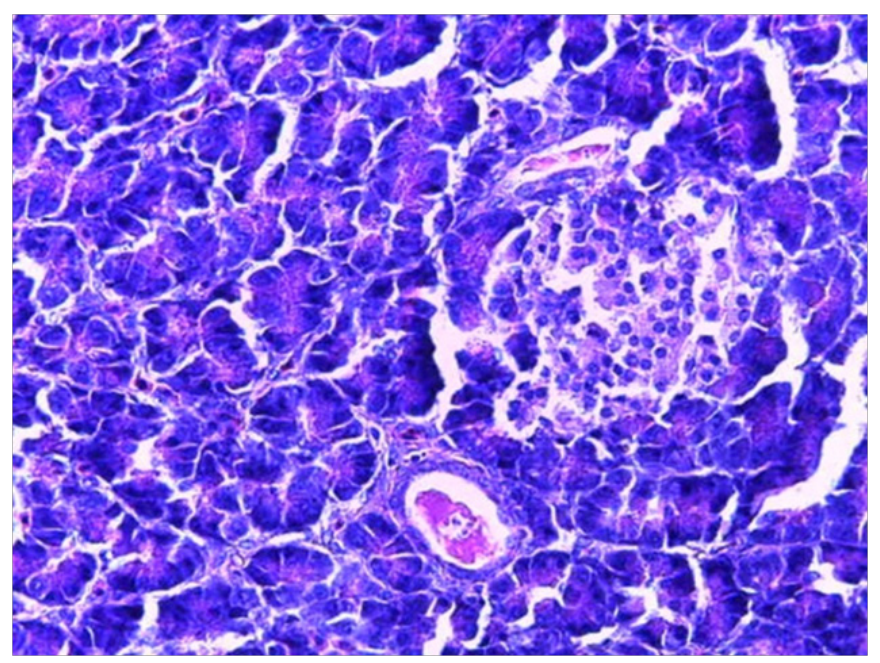

Fig. 12. Pancreas of a 38-day-old bird

of the 1st experimental group 


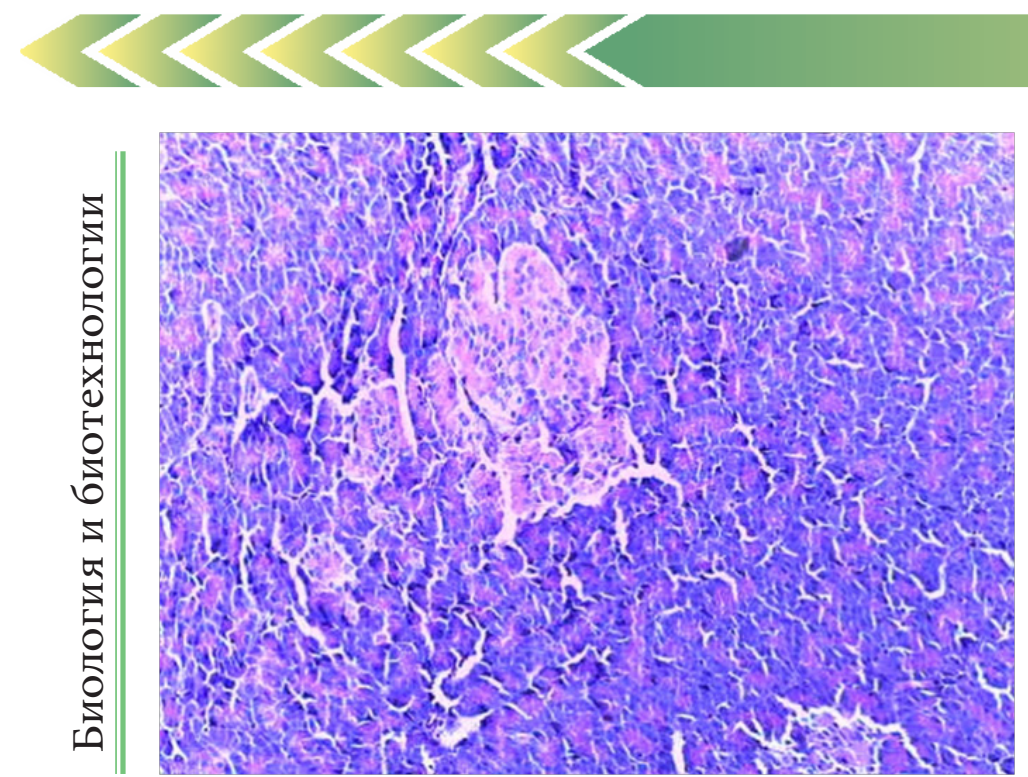

Fig. 13. Pancreas of a 38-day-old control bird

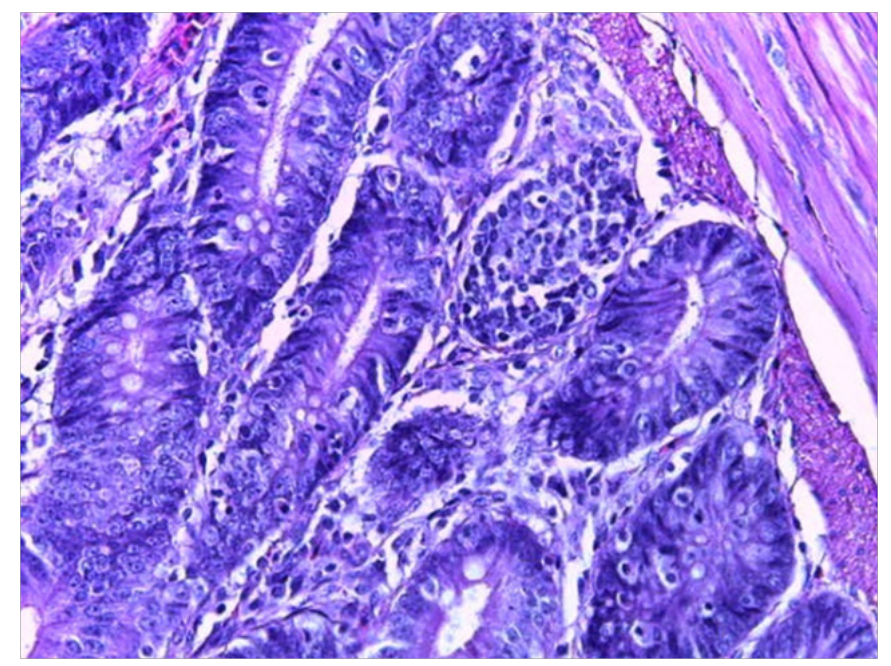

Fig. 15. Duodenum of a 38-day-old bird in the 2 nd experimental group

Discussion and Conclusion

Based on the totality of the obtained results, it can be concluded that the use of a complex phytobiotic feed additive in addition to the main diet and instead of feed antibiotics has a positive effect on metabolic processes in the bird's body. Thus, according to the data of the balance experiment, it was found that replacing feed antibiotics in the diet with the studied preparation increases the digestibility of fiber by $11 \%$ and fat by $4.9 \%$ by broilers. With the additional inclusion of the test fodder in the compound fodder, the digestibility of fiber increases by $3.2 \%$.

Histological analysis of the digestive tract showed that in the duodenal mucosa of the chickens of the $2^{\text {nd }}$ experimental group, which received a preparation containing phytobiotics and protected organic acids instead of a feed antibiotic, moderate secretion was noted, that is, the processes of digestion of

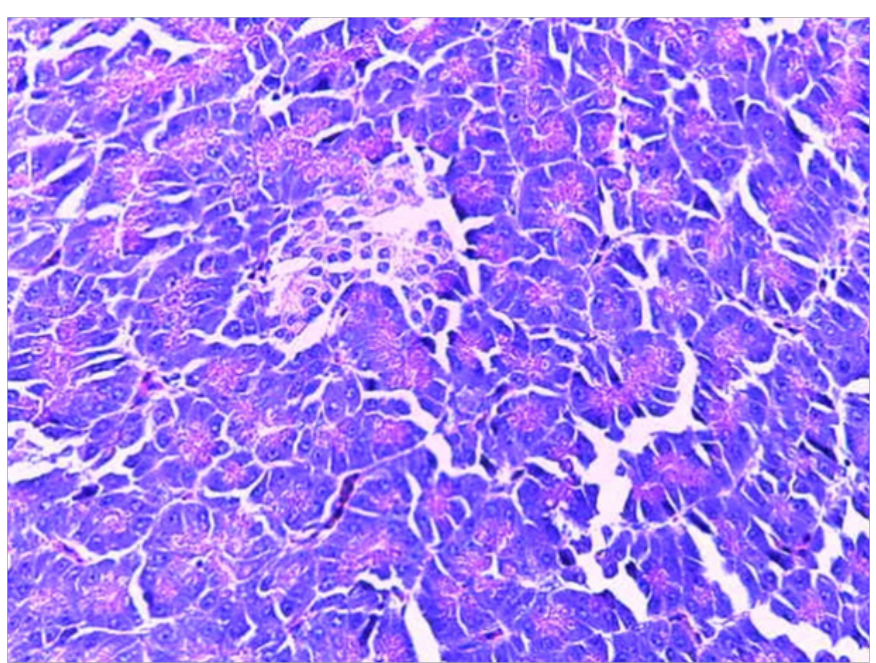

Fig. 14. Pancreas of a 38-day-old control bird

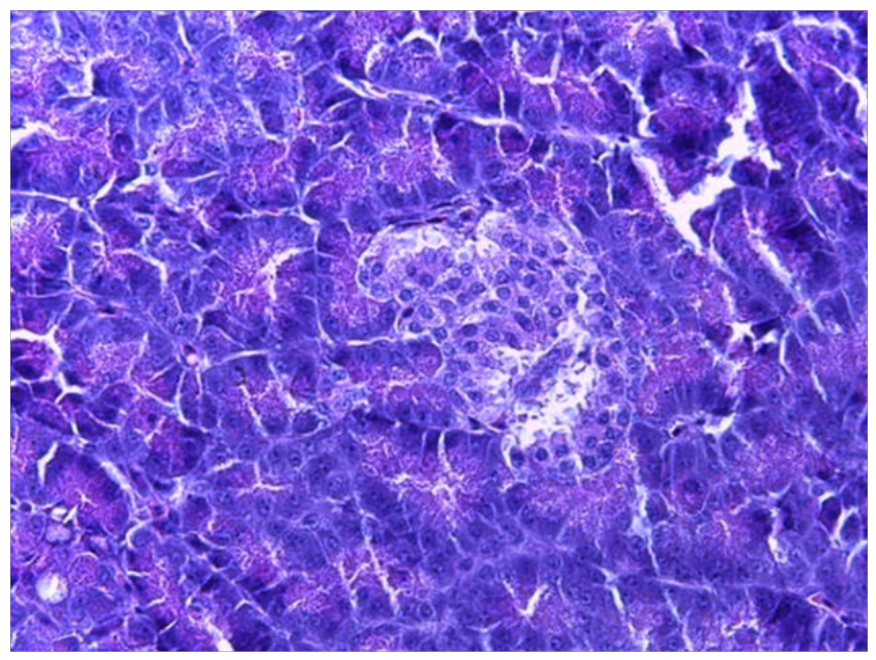

Fig. 16. Pancreas of a 38-day-old bird in the 2 nd experimental group

feed with the active work of the pancreas ensure the normal life of the bird without manifestations of pathological conditions. In $1^{\text {st }}$ experimental group, where the drug was included in addition to the main diet, there were also no pathological changes in the form of inflammation and necrobiosis, and it looked more positive compared to the control group, nevertheless, the general complex of processes noted in $2^{\text {nd }}$ experimental group has advantages over $1^{\text {st }}$ experienced group.

The positive effect of the use of the studied drug is due to its constituent substances, which, due to antibacterial, antiinflammatory and antioxidant properties, prevent the development of pathogenic microflora in the gastrointestinal tract of the bird, while the enzymatic activity of the internal secretion organs is stimulated, which leads to better digestion and assimilation nutrients in the body of chickens.

\section{References}

1. Dzhanarslanov R. Broiler bez antibiotikov - trend budushchego [Broiler without antibiotics-the trend of the future] [eresource] // Agroinvestor.ru. URL: https://www.agroinvestor.ru/column/rizvan-dzhanarslanov/30096-broyler-bez-antibiotikovtrend-budushchego (appeal date: 08.11.2019). (In Russian.)

2. Iliesh V. D., Goriacheva M. M. Probiotiki v zhivotnovodstve - put' k kachestvu i bezopasnosti produktov pitaniya [Probiotics in animal husbandry - the way to food quality and safety] [e-resource] // Dairynews.ru: Digest of the Russian dairy 


\section{Agrarian Bulletin of the Urals No. 12 (203), 2020}

market news. URL: https://www.dairynews.ru/news/probiotiki-v-zhivotnovodstve-put-k-kachestvu-i-bez.html (appeal date: 03.08.2020). (In Russian.)

3. Shepetkina S. V., Novikova O. B., Zabrovskaya A. V., Terletskiy V. P., Tyshchenko V. I. Sovremennye printsipy antibiotikoterapii $\mathrm{v}$ ptitsevodstve [Modern principles of antibiotic therapy in poultry farming] // SPb.: Izdatel'stvo FGBOU VPO "SPbGA-VM", 2015. 160 p. (In Russian.)

4. Kuramshin A. Polimernye nanochastitsy - novoe oruzhie v bor'be s bakteriyami? [Polymer nanoparticles - a new weapon in the fight against bacteria?] [e-resource]. URL: https://kpfu.ru/chemistry/novosti-himii-goryachej-strokoj/polimernye-nanochasticy-mdash-novoe-oruzhie-v.html (appeal date: 03.08.2020). (In Russian.)

5. Ustoichivost' $\mathrm{k}$ antibiotikam - ser'eznaya ugroza obshchestvennomu zdravookhraneniyu [Antibiotic resistance is a serious threat to public health] [e-resource]. URL: https:/www.who.int/mediacentre/news/releases/2014/amr-report/ru (appeal date: 03.08. 2020). (In Russian.)

6. Vilsma G., Sigall S., Nufer A. I. Puti ozdorovleniya kishechnika sviney i ptitsy v usloviyakh sovremennogo promyshlennogo proizvodstva [Ways of improving the intestines of pigs and poultry in modern industrial production] // Issues of Legal Regulation in Veterinary Medicine. 2015. No. 2. Pp. 277-279. (In Russian.)

7. Shatskikh E. V., Galiev D. M., Nufer A. I. Produktivnost' broylerov pri zamene v ratsione kormovykh antibiotikov na rostostimuliruyushchie dobavki [Productivity of broilers when replacing feed antibiotics in the diet with growth-stimulating additives] // Poultry and chiken products. 2019. No. 6. Pp. 26-28. (In Russian.)

8. Shatskikh E. V., Vasilyeva O. A., Nufer A. I. Al'ternativnye puti zameny kormovykh antibiotikov [Alternative ways to replace feed antibiotics] // Effektivnoe zhivotnovodstvo. 2019. No. 4. Pp. 66-68. (In Russian.)

9. Egorov I. A., Egorova T. V., Krivoruchko L. I., Brylin A. P., Belyavskaya V. A., Bol'shakova D. S. Probiotik v kombikormakh dlya tsyplyat-broylerov [Probiotic in mixed feed for broiler chickens] // Ptitsevodstvo. 2019. No. 3. Pp. 25-28. (In Russian.)

10. Kanardov P. Antibiotiki v zhivotnovodstve. Zapreti' nel'zya razreshit' [Antibiotics in animal husbandry. You can not deny to allow] // Tsenovik. Agricultural Review. 2017. No. 9. Pp. 22. (In Russian.)

11. Salomatov E. A., Slobozhaninov K. V., Vereshchagina E. N., Paderina R. V. Ispol'zovanie probiotikov v kormlenii kurnesushek [The use of probiotics in the feeding of laying hens] // Ptitsevodstvo. 2019. No. 10. Pp. 48-50. (In Russian.)

12. Ramires D., Gossens T. Alternativa antibiotikam. Dobavki ADIMIKS $®$ Precision i APEKS $®$ v kormlenii broylerov [Alternative to antibiotics. ADIMIX ${ }^{\circledR}$ Precision and APEX ${ }^{\circledR}$ additives in broiler feeding] // Animal husbandry of Russia. Thematic issue. 2017. No. 3. Pp. 53-56. (In Russian.)

13. Shatskikh E. V., Vasina O. V. Organicheskie podkisliteli dlya vyrashchivaniya broylerov [Organic acidifiers for growing broilers] // Agrarian Bulletin of the Urals. 2011. No. 10 (89). Pp. 39-40. (In Russian.)

14. Ovchinnikov A. A., Ovchinnikova L. Yu., Konovalov D. A. Immunnyy status organizma myasnykh kur pri ispol'zovanii probiotikov v ratsione [Immune status of the body of meat chickens when using probiotics in the diet] // Ptitsevodstvo. 2019. No. 5. Pp. 43-47. (In Russian.)

15. Egorov I. A., Egorova T. A., Lenkova T. N., Vertiprakhov V. G., Manukian V. A., Nikonov, I. N. Grozina A. A., Filippova V. A., Iyldyrym E. A., Il'ina L. A., Dubrovin A. V., Laptev G. Yu. Zameshchenie kormovykh antibiotikov v ratsionakh. Soobshchenie II. Mikrobiota kishechnika i produktivnost' miasnykh kur (Gallus gallus L.) na fone fitobiotika [Replacement of feed antibiotics in diets. Message II. Gut microbiota and productivity of meat chickens (Gallus gallus L.) against the background of phytobiotics] // Sel'skokhozyaistvennaya biologiya. 2019. T. 54. No. 4. Pp. 798-809. (In Russian.)

16. Gadde U., Kim W. H., Oh S. T., Lillehoj. Hyun S. Alternatives to antibiotics for maximizing growth performance and feed efficiency in poultry: a review // Animal health research reviews.2017. Vol. 18. No. 1. Pp. 26-45.

\section{Authors'information:}

Elena V. Shatskikh ${ }^{1}$, doctor of biological sciences, professor, head of the department of zooengineering, ORCID 0000-0001-5086-6353, AuthorID 478964; +7922 107-67-92,evshackih@yandex.ru

Alena I. Nufer ${ }^{1}$, postgraduate student of the department of zooengineering, ORCID 0000-0001-9367-2225,

AuthorID 1087197; +7922 146-00-04,nufer@agroros-company.ru

Lyudmila I. Drozdova ${ }^{1}$, head of the department of morphology and expertise, doctor of veterinary sciences, professor, ORCID 0000-0001-9689-1781, AuthorID 599715; +7950636-60-30,drozdova43@mail.ru

${ }^{1}$ Ural State Agrarian University, Ekaterinburg, Russia 